\title{
ETNOZOOLOGI UNTUK RITUAL ADAT DAN MISTIS MASYARAKAT MELAYU DESA NANGA BETUNG KECAMATAN BOYAN TANJUNG KABUPATEN KAPUAS HULU
}

\author{
(Ethnozoological for Traditional Ritualsand Mystical of Malay Society Nanga Betung Village, \\ Boyan Tanjung District, Kapuas Hulu Regency)
}

\author{
Addrama Putra Sukma, M. Sofwan Anwari, Hafiz Ardian \\ Fakultas Kehutanan Universitas Tanjungpura Jl. Daya Nasional Pontianak 78124 \\ E-mail: addrama17@gmail.com
}

\begin{abstract}
The local people of Kalimantansince the ancestors era until the present from various tribes still depend on nature. They use animals for daily needs such as consumption needs (protein), traditional ritual needs, treatment, supernatural and commercial activities. Malay community of Nanga Betung Village, Boyan Tanjung Subdistrict, Kapuas Hulu Regency has diversity in the utilization of fauna both for food, medicine, traditional ceremonies and arts. One of their cultures is still using animals around them for traditionalrituals and mystical. The purpose of this study is to obtain data on the species of animals used for traditional and mystical rituals and how they can be used by the Malay community of Nanga Betung Village. Data collection methods that is by field survey and interview and direct observation in the field. The selection of respondents using the snowball sampling technique. The results showed the amount of species used for traditional rituals and mystical by the Malay community of Nanga Betung Village, Boyan Tanjung Subdistrict, Kapuas Hulu Regency, there are 8 species of animals from 8 families. The average of each family consists of only one species. Animal parts that are used for traditional rituals and mystical are in the whole body, voice, egg, blood, and shell. The way to use it is by the whole body and blood of the animal for ritual salvation of people who will to give birth and the safety of the house that is occupied, the sound of the animals as a sign and the animalsantidote to the spirits.
\end{abstract}

Keywords: Etnozoology, Malay Tribe, Mystical, Nanga Betung, Traditional Rituals.

\section{PENDAHULUAN}

Keberadaan flora dan fauna tidak dapat dipisahkan dengan kehidupan manusia,mereka memanfaatkan berbagai sumberdaya di sekitar untuk memenuhi kebutuhan hidupnya (Suparlan, 2005). Suku-suku asli yang mendiami suatu tempat sangat mengenal sumberdaya hayati di lingkungan yang telah beradaptasi dan terlatih untuk memanfaatkan flora dan fauna (Indrawan et al. 2007). Kekayaan alam ini dimanfaatkan oleh sebagian besar masyarakat pedalaman Kalimantan salah satunya pemanfaatan fauna atau satwa. Masyarakat sekitar hutan menjadikan hutan sebagai tumpuan hidup karena di dalam hutan terdapat satwa yang membentuk interaksi dan saling terkait (Wollenberg, 2001).

Sejak zaman nenek moyang hingga saat ini masyarakat lokal Kalimantan dari berbagai macam suku masih menggantungkan hidupnya pada 
alam.Mereka memanfaatkan hasil alam berupa satwa untuk keperluan sehari-hari seperti kebutuhan konsumsi (protein), keperluan ritual adat, pengobatan, kegiatan supranatural dan komersial. Satwa juga bisa dimanfaatkan sebagai kesenian, pertanda menurut keyakinan setempat dan indikator lingkungan. Hubungan manusia dalam memanfaatkan satwa disebut juga etnozoologi. Pemanfaatan flora dan fauna telah dilakukan oleh berbagai etnis yang ada di Kalimantan sejak dulu untuk memenuhi kebutuhan hidupnya, salah satunya sebagai sumber bahan pangan, obat-obatan, sarana ritual kebudayaan dan kepentingan ekonomi subsisten.

Masyarakat yang berada di Desa Nanga Betung, Kecamatan Boyan Tanjung, Kabupaten Kapuas Hulu merupakan mayoritas suku Melayu yang masih bergantung kepada hasil alam. Masyarakat memiliki keanekaragaman dalam pemanfaatan fauna baik untuk bahan pangan, obat-obatan, upacara adat dan kesenian. Salah satu budaya mereka yaitu masih memanfaatan hewan untuk ritual adat dan mistis. Pengetahuan tentang pemanfaatan sumber daya alam telah dipraktekan sejak zaman nenek moyang. Salah satu pemahaman mereka adalah pemanfaatan fauna atau hewan. Masyarakat Melayu Desa Nanga Betung memiliki pengetahuan dalam hal pemanfaatan satwa, satwa yang dimanfaatkan dapat berasal dari alam atau peliharaan. Kemampuan tentang pemanfaatan satwa diperoleh dari pengalaman yang diwariskan secara turuntemurun. Tujuan penelitian ini adalah mendapatkan data jenis-jenis hewan yang dimanfaatkan untuk ritual adat dan mistis serta bagaimana cara pemanfaatannya oleh masyarakat Melayu Desa Nanga Betung Kecamatan Boyan Tanjung Kabupaten Kapuas Hulu.

\section{METODE PENELITIAN}

Penelitian ini dilaksanakan pada tanggal 20 November - 11 Desember 2018 di Desa Nanga Betung Kecamatan Boyan Tanjung Kabupaten Kapuas Hulu yang terdiri dari 3 Dusun yaitu Dusun Betung, Dusun Kalang, dan Dusun Bantas.Sebagai objek dari penelitian ini adalah Masyarakat Melayu Desa Nanga Betung dan Hewan.Adapun alat-alat dan bahan yang digunakan dalam penelitian ini yaitu kuisioner untuk responden terpilih, alat rekaman untuk merekam kegiatan, kamera untuk dokumentasi.

Metode Pengumpulan data dilakukan dengan metode survey dan wawancara serta pengamatan langsung di lapangan. Pemilihan responden dilakukan dengan menggunakan teknik snowball sampling, yaitu dengan menentukan responden kunci untuk kemudian menentukan responden lainnya berdasarkan informasi dari responden sebelumnya, demikian juga untuk seterusnya. Responden kunci adalah orang yang memiliki pengetahuan luas mengenai jenis hewan, cara mendapatkannya, bagian yang digunakan, cara memanfaatkannya serta kegunaannya. Wawancara yang telah dilakukan, keterangannya harus dilakukan pencatatan yang lengkap mengenai keterangan jenisjenis satwa yang dimanfaatkan oleh masyarakat setempat. Penelitian ini menggunakan responden dari kepala desa, kepala dusun, kepala adat, dukun, tabib, 
pengguna, orang tua, pemburu, ibu-ibu dan sebagainya.

Analisa data yang digunakan adalah metode deskriftif kualitatif, yaitu mendeskrifsikan data yang dikumpulkan berupa kata-kata, gambar dan bukan angka. Data yang berasal dari wawancara, catatan lapangan, jenis hewan yang dimanfaatkan, cara mendapatkan dan memanfaatkannya serta kegunaannya.

HASIL DAN PEMBAHASAN Jenis Satwa Yang Dimanfaatkan Untuk Ritual Adat dan Mistis
Berdasarkan penelitian yang dilakukan bahwa hasil wawancara diperoleh sebanyak 8 jenis satwa dari 5 famili yang dimanfaatkan oleh masyarakat Melayu Desa Nanga Betung untuk Ritual Adat atau Mistis.Masyarakat Suku Melayu Desa Nanga Betung masih mempunyai kepercayaan terhadap hewanhewantertentu yang memiliki nilai mistis dan terdapat hewanyang juga biasanya digunakan untuk upacara ritual adat serta sebagai pertanda. Jenis hewan yang dimanfaatkan sebagai ritual adat dan mistis tersebut disajikan pada Tabel 1 .

Tabel 1. Pemanfaatan Satwa untuk Ritual Adat dan Mistis (Used for traditional ritual andmystical).

\begin{tabular}{|c|c|c|c|c|c|c|}
\hline No & Nama Lokal & Nama Ilmiah & Ritual & Mistis & $\begin{array}{l}\text { Bagian } \\
\text { yang } \\
\text { diigunakan }\end{array}$ & Makna \\
\hline 1 & Manok kampong & Gallus domesticus & $\sqrt{ }$ & & $\begin{array}{l}\text { Seluruh } \\
\text { tubuh, telur, } \\
\text { darah }\end{array}$ & $\begin{array}{l}\text { Agar pada saat persalinan dapat } \\
\text { dengan mudah melahirkan, dan } \\
\text { rumah yang ditempati aman dan } \\
\text { nyaman }\end{array}$ \\
\hline 2 & Ucin & Felis catus & & $\sqrt{ }$ & $\begin{array}{l}\text { Air bekas } \\
\text { minuman } \\
\text { kucing di } \\
\text { malam jum'at }\end{array}$ & $\begin{array}{l}\text { Air selusuh digunakan untuk ibu } \\
\text { hamil agar } \\
\text { persalinan } \\
\text { meminumnya }\end{array}$ \\
\hline 3 & Burung antu & Tyto alba & & $\sqrt{ }$ & Suara & $\begin{array}{l}\text { Jika pada malam hari ada suara } \\
\text { burung hantu, dipercaya ada } \\
\text { makhluk halus disekitarnya }\end{array}$ \\
\hline 4 & Burung gagak & Corpus enca & & $\sqrt{ }$ & Suara & $\begin{array}{l}\text { Jika ada burung gagak yang } \\
\text { bersuara sambil terbang, diyakini } \\
\text { sedang memberi tahu bahwa ada } \\
\text { orang yang melahirkan }\end{array}$ \\
\hline 5 & Prengka & Bufo melanosticus & & $\sqrt{ }$ & Suara & $\begin{array}{l}\text { Suara prengka atau kodok ini } \\
\text { dipercaya akan turunnya hujan }\end{array}$ \\
\hline 6 & Biawak & Varanus salvator & & $\sqrt{ }$ & Seluruh tubuh & $\begin{array}{l}\text { Biawak yang masuk kedalam } \\
\text { rumah merupakan pertanda buruk }\end{array}$ \\
\hline 7 & Ketuntong & Helix pomatia & & $\sqrt{ }$ & Cangkang & 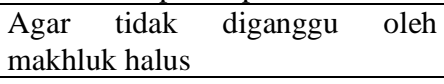 \\
\hline 8 & Ikan tapah & Wallago leerii & & $\sqrt{ }$ & Seluruh tubuh & $\begin{array}{l}\text { Orang yang memakan ikan ini } \\
\text { tidak diperbolehkan keladang, } \\
\text { karena akan membuat padi gagal } \\
\text { panen }\end{array}$ \\
\hline
\end{tabular}

Sumber : Data Hasil Wawancara Bersama Resaponden Terpilih Desa Nanga Betung. (2018) 


\section{Bagian Hewan yang Dimanfaatkan dan Cara Pemanfaatan Hewan untuk Ritual Adat dan Mistis}

Ayam kampong merupakan hewan yang banyak dipelihara masyarakat, ayam kampong digunakan untuk ritual Sengkolan Kanong (selamatan kehamilan) dan upacara ngontak rumah (meletakan tiang pertama). Ritual sengkolan kanong ayam yang masih hidup dan yang digunakan adalah ayam betina, dengan dilakukan oleh bidan kampong (dukun bayi) melakukan ritual dengan cara ayam tersebut diputar mengelilingi pasangan yang melakukan selamatan, diputar kearah kiri 6 kali, dan ke kanan 7 kali dengan bomang atau mantra yang berisikan do'a, adapun mantra tersebut berbunyi "aku tuk nopas ngadap kiblat muang pantang bai yang nak bait". Ritual ini bertujuan agar harapannya anak di dalam kandungan nantinya sehat dan proses persalinan berlangsung dengan lancar seperti ayam yang mengeluarkan telurnya.

Proses selanjutnya melakukan Tepung Tawar, kemudian bidan kampong menempelkan telur ayam kampung tersebut kepusar wanita dengan membaca Basmalah kemudian pembacaan bomang atau mantra "aku bukan makai kuasa aku, aku makai kuasa Allah La haula wa la quwwata illa billah". Sebagai penutup dibacakan do'a selamat dan do'a tolak bala.

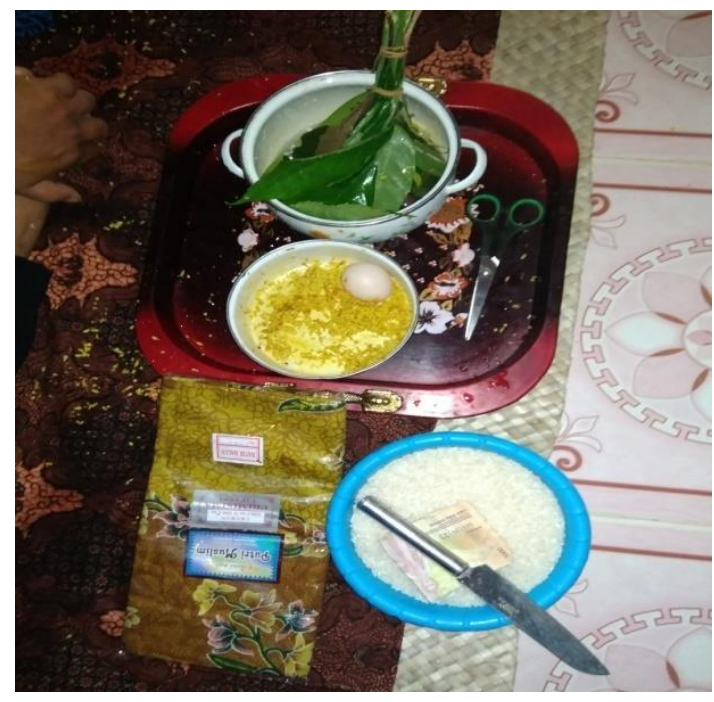

(a).

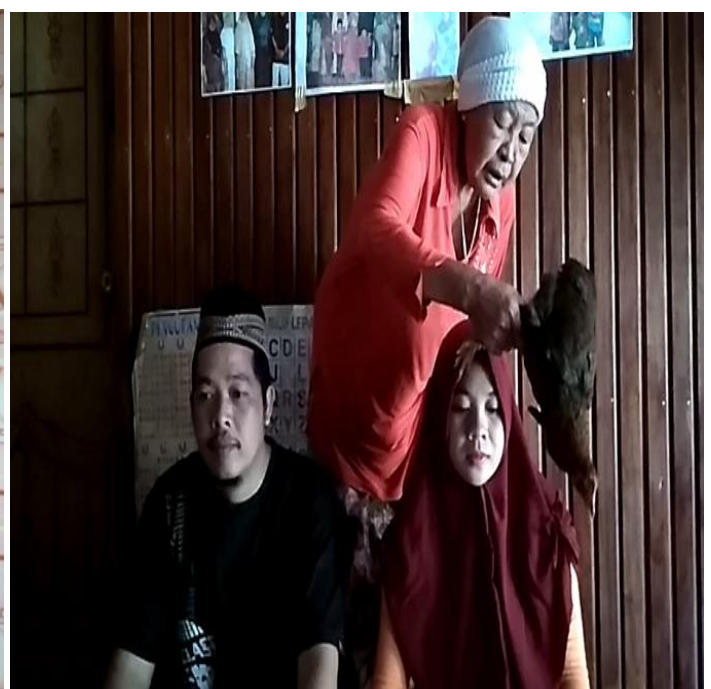

(b).

Gambar 1. Ritual Adat Sengkolan Kanong, (a). Karat atau bahan untuk syarat ritual (b). Proses ritual(Sengkolan Kanong Traditional Ritual. (a). Karat or materials for ritual requirement. (b). process ritual)

Upacara ngontak rumah, ayam yang digunakan tidak ada pantangan baik itu jantan maupun betina. Proses ritualnya yaitu dengan menggosokkan ayam tersebut terlebih dahulu ke tiang yang nantinya akan ditancapkan, 
kemudian ayam disembelih dengan menyebut nama Allah SWT di atas lubang yang nantinya akan ditancapkan tiang pertama agar darah ayam yang telah disembelih tadi menetes ke dalam lubang tersebut, dan dimasukkan juga benda lain ke dalam lubang berupa kelereng, beras ketan 7 biji dan bahan lainnya yang dipercaya masyarakat sebagai syarat-syaratnya dan nantinya juga ditutup dengan pembacaan do'a selamat. Ritual ini bertujuan agar penghuni rumah dapat menempati rumah tersebut dengan nyaman dan mudah mendapatkan rezeki.

Kucing merupakan hewan peliharaan sebagian orang yang hobi memeliharanya, namun di kalangan masyarakat Desa Nanga Betung, kucing juga memiliki nilai mistis. Air bekas minuman kucing di malam jum'at ternyata dipercaya dapat memperlancar persalinan bagi ibu-ibu yang akan melakukan persalinan. Caranya air bekas minuman kucing tersebut nantinya akan dibacakan do'a tertentu oleh orang yang bisa membacakan tawar (do'a) dan diminumkan kepada ibu-ibu yang akan melahirkan. Air bekas minuman kucing di malam jum'at yang telah dibacakan tersebut oleh orang-orang Desa Nanga Betung dinamakan air selusuh.

Masyarakat Desa Nanga Betung percaya bahwa burung hantu dapat melihat makhluk halus. Burung hantu yang berbunyi di dekat rumah pada malam hari berarti ada makhluk halus di sekitarnya. Perbedaan tidak terlalu jauh dengan masyarakat Dayak Bakati di
Desa Seluas kabupaten Bengkayang yang beranggapan bahwa burung hantu merupakan jelmaan dari makhluk halus sehingga banyak ditakuti sebagian masyarakat (Rusmiati dkk., 2018). Burung gagak juga memiliki pertanda tersendiri bagi masyarakat Desa Nanga Betung, jika burung gagak bersuara sambil terbang itu menandakan bahwa ada yang melahirkan di kampung tersebut atau di kampung-kampung tetangga.

Prengka (Bufo melanosticus) merupakan kodok yang habitatnya di tempat lembab memiliki pertanda yaitu jika kodok berbunyi dengan keras dan saling bersahut-sahutan dengan kodok lainnya merupakan pertanda akan turunnya hujan. Petani karet di Desa Nanga Betung menggunakan fenomena tersebut untuk mengetahui waktu akan turunnya hujan, artinya apabila pada waktu subuh kodok tersebut berbunyi saling bersahutan maka para petani tidak akan pergi untuk menorah karet mereka, karena dipercayai akan turunnya hujan. Masyarakat Desa Gurung Mali mempercayai kodok yang masuk ke dalam rumah sebagai pertanda bahwa pemilik rumah akan kesulitan keuangan (Dewin $d k k$., 2017).

Biawak merupakan salah satu reptil yang memiliki pertanda bagi masyarakat Desa Nanga Betung, jika ada rumah yang dimasuki oleh hewan ini maka rumah tersebut harus dibacakan do'a tolak bala. Biawak yang masuk kedalam rumah memiliki pertanda bahwa rumah yang dimasuki biawak tersebut nantinya akan 
mengalami musibah dan tidak mudah didatangi rezeki jika tidak segera dibacakaan tolak bala.

Ketuntong atau siput (Helix pomatia) adalah jenis siput darat yang memiliki ukuran yang cukup besar, cangkang hewan ini digunakan untuk menangkal gangguan mahluk halus pada bayi dan anak kecil.Cangkang ketuntong diikatkan bersamaan dengan buku yasin dan kulit kayu yang dalam bahasa masyarakat Nanga Betung disebut sampok pada tali ayunan yang biasa digunakannya.

Ikan tapah yang bernama latin Wallago micropogan dipercaya masyarakat apabila orang yang berladang padi dan orang tersebut memakan ikan tapah maka dilarang untuk pergi keladang pada hari itu, jika dia pergi maka akan membuat gagal panen pada ladang tersebut. Menurut para responden hal tersebut sangat ditakutkan masyarakat karena gagal panen merupakan petaka bagi mereka, masyarakat Desa Nanga Betung sangat berhati-hati dalam pantangan tersebut. Pemanfaatan hewan untuk Ritual Adat dan Mistisoleh masyarakat Melayu Desa Nanga Betung ini yaitu mulai dari seluruh badan sampai pada organ-organ tubuh lainnya. Pemanfaatan bagianbagian hewan ini dapat dilihat pada gambar 2.

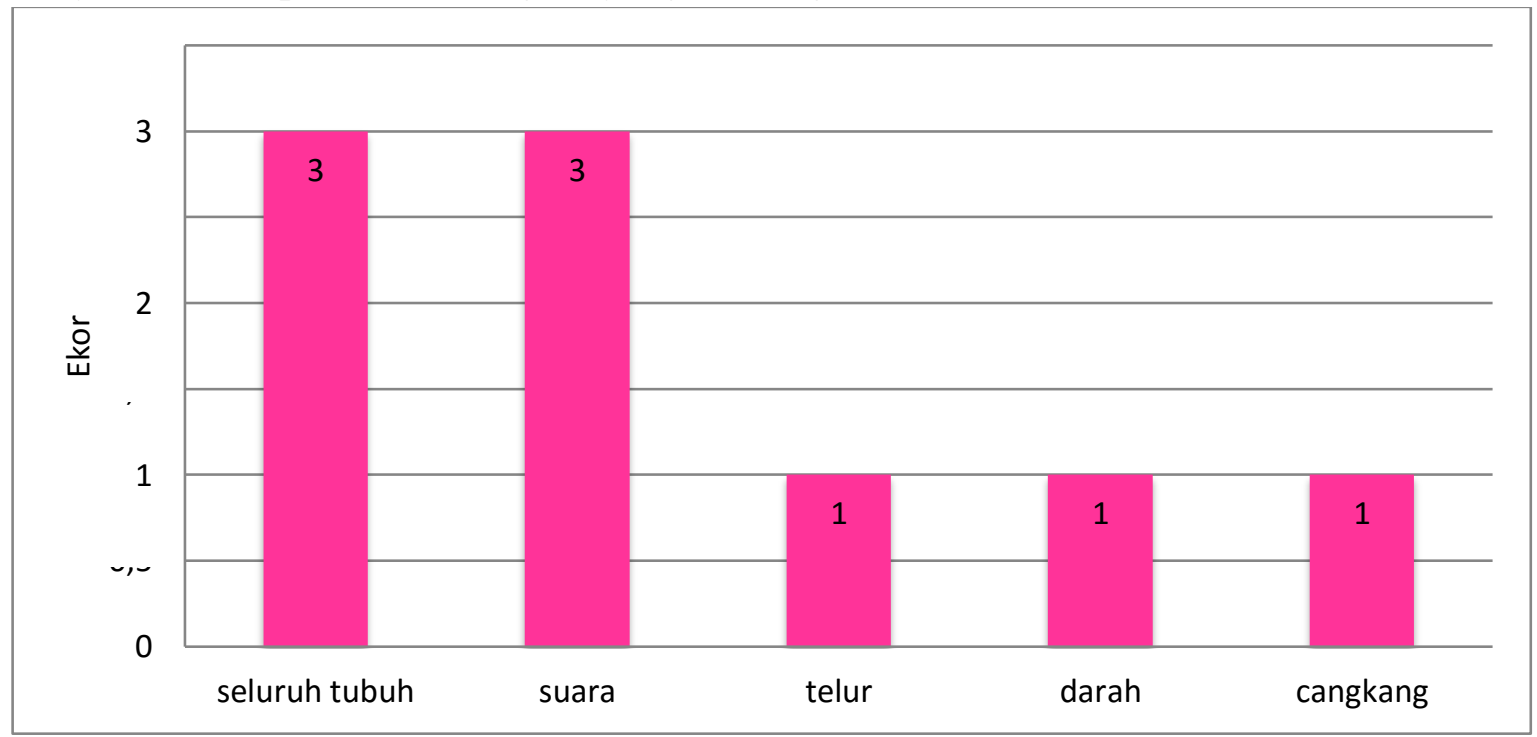

Gambar 2. Bagian satwa yang dimanfaatkan(parts of animals that are utilized)

Bagian hewan yang dimanfaatkan untuk ritual adat dan mistis terdiri atas seluruh tubuh dan suaraada 3 pemanfaatan, sedangkan untuk telur, darah dan cangkan masing-masing ada 1 pemanfaatan. Seluruh tubuh yang digunakan yaitu hewan ayam kampung (Gallus domesticus) untuk ritual, biawak (Varanus salvator) sebagai mistis, ikan tapah (Wallago leerii) sebagai mistis. Pemanfatan suara, yaitu burung hantu (Tyto alba) sebagai mistis, burung gagak (Corpus enca) sebagai mistis, kodok (Bufo melanosticus) sebagai mistis. Pemanfaatan telur digunakan untuk 
ritual adat Sengkolan Kanong, darah untuk ritual adat Ngontak Rumah, dan cangkang yang digunakan adalah ketuntong (Helix pomatia) sebagai mistis.

\section{Kesimpulan}

1. Jumlah jenis hewan yang dimanfaatkan untuk Ritual Adat dan Mistis oleh masyarakat Melayu Desa Nanga Betung, Kecamatan Boyan Tanjung, Kabupaten Kapuas Hulu, yaitu sebanyak 8 jenis hewan dari 8 famili. Rata-rata setiap famili hanya terdiri dari 1 spesies.

2. Bagian-bagian hewan yang dimanfaatkan untuk Ritual Adat dan Mistis yaitu pada bagian seluruh tubuh, suara, telur, darah, dan cangkang. Cara pemanfaatannya yaitu dengan cara seluruh tubuh dan darah dari hewan tersebut untuk ritual selamatan orang yang ingin melahirkan dan keselamatan rumah yang di tempati, suara sebagai pertanda dan cangkang penangkal makhluk halus.

\section{Saran}

Salah satu upaya yang dapat dilakukan untuk melestarikan satwa yang dilindungi ialah mengingatkan kembali nilai-nilai luhur yang dimiliki suku Melayu Desa Nanga Betung untuk memperkecil kemungkinan kelangkaan satwa yang mereka butuhkan.

\section{DAFTAR PUSTAKA}

Dewin LV, Anwari MS, Prayogo H. 2017. Kajian Etnozoologi Masyarakat Dayak Seberuang di Desa Gurung Mali Kecamatan Tempunak Kabupaten Sintang. Jurnal Hutan Lestari 5 (4): 978986.

Indrawan MR, Primac KB, SupriatnaJ. 2007. Biologi Konservasi. Edisi Revisi. Yayasan Obor Indonesia, Jakarta : xviii $+627 \mathrm{hlm}$

Rusmiati, Anwari MS, Tavita GE. 2018. Etnozoologi Masyarakat Dayak Bakati di Desa Seluas Kabupaten Bengkayang. Jurnal Hutan Lestari 6 (3): 594-604.

Suparlan P. 2005.Suku Bangsa dan Hubungan Antar Suku Bangsa. Cetakan Kedua. Yayasan Pengembangan Kajian Ilmu Kepolisian Press, Jakarta: 11-12.

Wollenberg E, Uluk A, Sudana A. 2001. Ketergantungan Masyarakat Dayak Terhadap Hutan di Sekitar Taman Nasional Kayan Mentarang.Bogor :CIFOR 